\title{
Actinomycin F1
}

National Cancer Institute

\section{Source}

National Cancer Institute. Actinomycin F1. NCI Thesaurus. Code C2844.

A chromopeptide antineoplastic antibiotic isolated from the bacterium Streptomyces chrysomallus. Actinomycin F1 intercalates into the minor groove of DNA and binds to topoisomerase II, leading to the inhibition of DNA replication and RNA and protein synthesis. ( $\mathrm{NClO4})$ 